\title{
The weed infestation of the potato (Solanum tuberosum L.) field under the conditions of growth biostymulators and herbicide applications
}

\author{
Zachwaszczenie łanu ziemniaka (Solanum tuberosum L.) \\ w warunkach stosowania biostymulatorów i herbicydu
}

\author{
Alicja Baranowska ${ }^{1 *}$, Iwona Mystkowska ${ }^{1}$, Krystyna Zarzecka
}

Summary

In the years 2015-2017 the field experiments were carried out in the region of Eastern Poland. The aim of the experiment was to determine the impact of potato crop management methods using growth bioregulators and herbicide on air-dry weed mass, that was determined prior row closure of potatoes and before harvesting tubers. The experiment was established on light soil, in a split-plot design in three replications. The following factors were investigated: I. three early potato varieties - Bellarosa, Owacja, Vineta, II. methods of applications of growth biostimulators: GreenOK Universal - PRO and Asahi SL and their combination with the herbicide Avatar 293 ZC. The aerial dry weight of weeds, both at the beginning of potato vegetation, as well as before the harvest of tubers, significantly differentiated varietal properties, methods of care and weather conditions prevailing in the years of research. The smallest value of the air-dry matter of weeds in both dates of the determinations was found in the Bellarosa cultivar on the following sites: 5 . for mechanically treated emergence, and after the final shape of ridge just before the emergence of potato plants sprayed with herbicide Avatar 293 ZC at a dose of $1.5 \mathrm{dm}^{3} / \mathrm{ha}$. The significant influence of weather factors on the value of the discussed feature was also proved.

Key words: weed control; GreenOK Universal - PRO; Asahi SL; Avatar 293 ZC

\section{Streszczenie}

Wyniki badań pochodzą z doświadczeń polowych przeprowadzonych w latach 2015-2017 w rejonie Polski wschodniej. Celem eksperymentu było określenie wpływu sposobów pielęgnacji łanu ziemniaka z zastosowaniem bioregulatorów wzrostu i herbicydu na powietrznie suchą masę chwastów, oznaczoną przed zwarciem rzędów ziemniaka i przed zbiorem bulw. Eksperyment założono na glebie lekkiej, w układzie split-plot, jako dwuczynnikowy w trzech powtórzeniach. Badanymi czynnikami były: I. trzy wczesne odmiany ziemniaka jadalnego - Bellarosa, Owacja, Vineta, II. sposoby stosowania biostymulatorów wzrostu: GreenOK Universal - PRO i Asahi SL oraz ich kombinacja z herbicydem Avatar 293 ZC. Powietrznie suchą masę chwastów zarówno na początku wegetacji ziemniaka, jak również przed zbiorem bulw, różnicowały istotnie właściwości odmianowe, sposoby pielęgnacji i warunki pogodowe panujące w latach badań. Najmniejszą wartość powietrznie suchej masy chwastów w obydwu terminach oznaczeń stwierdzono u odmiany Bellarosa na obiektach: 5. do wschodów pielęgnowanych mechanicznie, a po ostatecznym ukształtowaniu redlin tuż przed wschodami roślin ziemniaka opryskiwanych herbicydem Avatar 293 ZC w dawce 1,5 dm³/ha. Udowodniono również istotny wpływ czynników pogodowych na wartość omawianej cechy.

Słowa kluczowe: zniszczenie chwastów; GreenOK Universal - PRO; Asahi SL; Avatar 293 ZC

\footnotetext{
Państwowa Szkoła Wyższa im. Papieża Jana Pawła II w Białej Podlaskiej

Katedra Nauk Technicznych

Sidorska 95/97, 21-500 Biała Podlaska

${ }^{2}$ Uniwersytet Przyrodniczo-Humanistyczny w Siedlcach

Katedra Agrotechnologii

Prusa 14, 08-110 Siedlce

*corresponding author: alabar@tlen.pl
} 


\section{Wstęp / Introduction}

W uprawie ziemniaka dużym problemem jest zachwaszczenie plantacji, co związane jest $\mathrm{z}$ powolnym wzrostem Solanum tuberosum L. na początku wegetacji. Okres od posadzenia do wschodów wynosi zwykle od 45 do 60 dni. Ponadto ziemniak uprawiany jest w szerokiej rozstawie rzędów, najczęściej: $67,5 \mathrm{lub} 75 \mathrm{~cm}$, a nawet $90 \mathrm{~cm}$ (w uprawie na frytki i chipsy, zwłaszcza kreacje zachodnie). W konsekwencji stwarza to bardzo dobre warunki do rozwoju roślinności niepożądanej (Urbanowicz 2015).

Na plantacjach ziemniaka najczęściej występuje od 29 do 55 gatunków chwastów (Nowacki iPodolska2005).Zdaniem Zarzeckiej (2000) oraz Sawickiej i Pszczółkowskiego (2003), powietrznie sucha masa chwastów jest znacznie dokładniejszym miernikiem wyznaczającym wartości progowe zachwaszczenia, niż liczba gatunków chwastów, co oznacza, że szkodliwość chwastów w mniejszym stopniu zależy od ich liczby na jednostce powierzchni, niż od wytworzonej przez nie biomasy. Straty w plonie $S$. tuberosum z powodu zachwaszczenia wynoszą od 10 do $80 \%$. Chwasty są roślinami żywicielskimi wielu chorób i szkodników. Ponadto zachwaszczenie plantacji utrudnia zbiór, powoduje uszkodzenia mechaniczne bulw oraz wpływa na pogorszenie jakości zebranych plonów. Zwłaszcza wieloletnie gatunki chwastów poprzez silny system korzeniowy zmniejszają potencjał rozwoju bulw i powodują ich liczne uszkodzenia (Sawicka i Pszczółkowski 2003; Jovović i wsp. 2012).

Aktualnie zachwaszczenie plantacji ziemniaka wymusza potrzebę poszukiwania różnych metod pielęgnacji (Pytlarz-Kozicka 2002). O wyborze konkretnej metody regulacji zachwaszczenia najczęściej decydują względy ekonomiczne, a szczególnie ceny środków ochrony roślin. Z badań Urbanowicza (2012) wynika, że w małych, rodzinnych gospodarstwach odchwaszczanie plantacji ogranicza się głównie do wykonywania zabiegów mechanicznych oraz mechaniczno-chemicznych. Najczęściej stosuje się jeden zabieg herbicydowy przed wschodami roślin ziemniaka. Zdaniem autora metoda chemiczna regulacji zachwaszczenia ma szersze zastosowanie na dużych plantacjach, których celem jest uzyskanie wysokiej jakości bulw spełniających normy surowca przeznaczonego do przetwórstwa.

Według Gruczka (2004) oraz Zarzeckiej i Gugały (2004) zabiegi mechaniczne niszczą chwasty w $95-98 \%$, ale tylko wtedy, kiedy znajdują się one w fazie siewek, natomiast skuteczność tej metody maleje do $45-60 \%$, gdy chwasty są w pełni wschodów. Stosowanie herbicydów, w porównaniu z metodą mechaniczną zapewnia wysoką skuteczność regulacji zachwaszczenia nawet do $90-99 \%$.

W Polsce oraz we wszystkich państwach Unii Europejskiej obowiązują zasady dotyczące zrównoważonego stosowania środków ochrony roślin (Barabaś 2015). Poszukuje się nowoczesnych metod uprawy, które zmniejszają presję na środowisko (Gajewski i wsp. 2013; Kowalska 2016).
Wyrazem dbałości o środowisko i jakość zebranych plonów jest wprowadzenie do produkcji roślinnej preparatów klasyfikowanych jako biostymulatory, wspomagających naturalne procesy życiowe roślin oraz zwiększające ich odporność na warunki stresowe (Paradiković i wsp. 2011; Kołodziejczyk 2016).

W uprawie ziemniaka, badania nad zastosowaniem biostymulatorów koncentrują się głównie nad ich wpływem na wielkość i jakość plonu. Natomiast niewiele jest danych na temat wpływu bioregulatorów wzrostu na zachwaszczenie łanu, nie ma również wystarczających danych dotyczących łącznego ich stosowania z pestycydami bądź wyniki te są niejednoznaczne.

Celem eksperymentu było określenie wpływu pięciu sposobów pielęgnacji z zastosowaniem bioregulatorów wzrostu i herbicydu na zachwaszczenie w uprawie trzech wczesnych odmian ziemniaka jadalnego. Hipoteza badawcza zakładała, że zabiegi pielęgnacyjne z zastosowaniem herbicydu i biostymulatorów wzrostu ograniczą zachwaszczenie łanu ziemniaka.

\section{Materiały i metody / Materials and methods}

Badania polowe prowadzono w latach 2015-2017 w rejonie Polski wschodniej, w gminie Biała Podlaska, w województwie lubelskim. Eksperyment prowadzono na glebie lekkiej o odczynie kwaśnym. Doświadczenie założono jako dwuczynnikowe w układzie split-plot $w$ trzech powtórzeniach. Czynnikiem pierwszego rzędu były trzy odmiany ziemniaka: Bellarosa, Owacja i Vineta, a drugiego rzędu pięć sposobów pielęgnacji:

1. Obiekt standardowy - pielęgnacja mechaniczna do i po wschodach roślin ziemniaka, tj. do wschodów 3-krotne obredlanie i obredlanie $\mathrm{z}$ bronowaniem ( 1 raz obredlanie +1 raz obredlanie połączone $\mathrm{z}$ bronowaniem +1 raz obredlanie), a po wschodach 2-krotne obredlanie (bez biostymulatorów i herbicydu).

2. Do wschodów roślin ziemniaka pielęgnacja mechaniczna, a po wschodach bioaktywator GreenOK Universal PRO trzy razy dolistnie: $w$ dawce $0,10 \mathrm{dm}^{3} / \mathrm{ha}(\mathrm{BBCH}$ 13-19) $+0,15 \mathrm{dm}^{3} / \mathrm{ha}\left(\right.$ BBCH 31-35) $+0,15 \mathrm{dm}^{3} / \mathrm{ha}$ (BBCH 51-55).

3. Do wschodów roślin ziemniaka pielęgnacja mechaniczna, a po wschodach bioaktywator Asahi SL trzy razy dolistnie $\mathrm{w}$ dawce $0,50 \mathrm{dm}^{3} / \mathrm{ha}(\mathrm{BBCH}$ 13-19) $+0,50 \mathrm{dm}^{3} / \mathrm{ha}($ BBCH $31-35)+0,50 \mathrm{dm}^{3} / \mathrm{ha}$ (BBCH 51-55).

4. Do wschodów pielęgnacja mechaniczna, a po ostatecznym ukształtowaniu redlin tuż przed wschodami roślin (BBCH 00-05) herbicyd Avatar 293 ZC w dawce $1,5 \mathrm{dm}^{3} /$ ha. Po wschodach trzykrotna aplikacja bioaktywatora GreenOK Universal - PRO w dawce $0,10 \mathrm{dm}^{3} / \mathrm{ha}(\mathrm{BBCH} 13-19)+0,15 \mathrm{dm}^{3} / \mathrm{ha}(\mathrm{BBCH} 31-35)$ $+0,15 \mathrm{dm}^{3} / \mathrm{ha}$ (BBCH 51-55). 
5. Do wschodów pielęgnacja mechaniczna, a po ostatecznym ukształtowaniu redlin przed wschodami roślin ziemniaka herbicyd Avatar $293 \mathrm{ZC}$ w dawce 1,5 dm 3 /ha (BBCH 00-05).

Preparat Asahi SL jest bioregulatorem wzrostu, którego substancję czynną stanowi mieszanina soli sodowych: paranitrofenolanu sodu, orto-nitrofenolanu sodu oraz 5-nitrogwajakolanu sodu. W krajach europejskich znany jest także pod nazwą handlową Atonik, a w Stanach Zjednoczonych Ameryki jako Chaperone (Czeczko i Mikos-Bielak 1997; Babuška 2004).

Preparat GreenOK Universal - PRO, zgodnie z informacją producenta (Łotewski Instytut Substancji Humusowych) jest płynnym nawozem organicznym z efektem biostymulującym, składającym się z koncentratu substancji humusowych, aktywizujących procesy życiowe roślin. W prowadzonym eksperymencie biostymulatory: Asahi SL oraz GreenOK Universal - PRO stosowano w dni pochmurne, w godzinach popołudniowych. Zastosowany w doświadczeniu preparat Avatar 293 ZC jest środkiem chwastobójczym, w formie zawiesiny kapsuł w cieczy do rozcieńczania wodą. Stosowany jest doglebowo, przed wschodami roślin na wilgotną glebę. Substancję czynną preparatu stanowi chlomazon [substancja z grupy izoksazolidionów - $60 \mathrm{~g} / \mathrm{dm}^{3}(5,13 \%)$ ] i metrybuzyna [substancja $\mathrm{z}$ grupy triazynonów $\left.-233 \mathrm{~g} / \mathrm{dm}^{3}(20,64 \%)\right]$.

W okresie wegetacji plantację ziemniaka chroniono insektycydami: Actara $25 \mathrm{WG}$ (tiametoksam $250 \mathrm{~g} / \mathrm{kg}$ ) w dawce $0,08 \mathrm{~kg} / \mathrm{ha}$ i Calypso $480 \mathrm{SC}$ (tiachlopryd $480 \mathrm{~g} / \mathrm{dm}^{3}$ ) w dawce $0,1 \mathrm{dm}^{3} /$ ha oraz fungicydami: Copper Max New $50 \mathrm{WP}$ (miedź - $500 \mathrm{~g} / \mathrm{kg}$ ) w dawce $2,0 \mathrm{~kg} / \mathrm{ha}$ i Dithane Neo Tec $75 \mathrm{WG}$ (mankozeb $750 \mathrm{~g} / \mathrm{kg}$ ) w dawce $2,0 \mathrm{~kg} / \mathrm{ha}$.

Do wykonania zabiegów chemicznych użyto opryskiwacza akumulatorowego, wyposażonego w standardową dyszę płaskostrumieniową (015-80, zgodnie z normą ISO), ciśnienie robocze wynosiło 1,4-2,6 bara, a wydatek cieczy $0,44-0,56 \mathrm{l} / \mathrm{min}$.

Jesienią, w każdym roku prowadzenia doświadczenia stosowano nawóz naturalny - obornik w dawce 25,0 t/ha oraz nawożenie mineralne fosforowo-potasowe w ilości $\mathrm{P}-44,0 \mathrm{~kg} / \mathrm{ha}$ (superfosfat potrójny 46\%) i K - 124,5 kg/ha (sól potasowa $60 \%$ ), a wiosną nawożenie azotowe (saletra amonowa 34\%) w dawce $100 \mathrm{~kg} \mathrm{~N} / \mathrm{ha}$. Bulwy ziemniaka sadzono w drugiej dekadzie kwietna (w 2015 i 2016 roku) i w trzeciej dekadzie kwietnia (w 2017 roku). Powierzchnia poletek do zbioru wynosiła $20 \mathrm{~m}^{2}$. Zbioru dokonywano w fazie pełnej dojrzałości technologicznej bulw.

Analizę zachwaszczenia poletek wykonano metodą ramkowo-wagową w dwóch terminach: 2-3 tygodnie po zastosowaniu herbicydu (przed zwarciem rzędów) i pod koniec wegetacji roślin ziemniaka (1-2 tygodnie przed zbiorem bulw), określając powietrznie suchą masę chwastów na powierzchni $1 \mathrm{~m}^{2}$ (Roztropowicz 1999). Skuteczność chwastobójczą (udział liczby zniszczonych chwastów) wyrażano w procentach w stosunku do obiektu kontrolnego, pielęgnowanego wyłącznie mechanicznie i przedstawiono dla obiektów 4 i 5, na których stosowano herbicyd Avatar 293 ZC oraz trzykrotną aplikację biostymulatora GreenOK Universal - PRO (obiekt 4), bądź też tylko herbicyd Avatar 293 ZC (obiekt 5) (Badowski i wsp. 2001).

Wyniki badań opracowano statystycznie za pomocą analizy wariancji, a istotność różnic testowano testem Tukeya przy poziomie istotności $\mathrm{p}=0,05$.

Warunki meteorologiczne w okresie wegetacji ziemniaka przedstawiono $\mathrm{w}$ tabeli 1. Dane pochodzą ze Stacji Meteorologicznej Centralnego Ośrodka Badania Odmian Roślin Uprawnych (COBORU) w Słupi Wielkiej i zostały sporządzone dla Stacji Doświadczalnej Oceny Odmian w Ciciborze Dużym, zlokalizowanej w pobliżu Białej Podlaskiej.

Podczas prowadzenia eksperymentu panowały zróżnicowane warunki pogodowe. Najbardziej wilgotny był sezon wegetacyjny 2017 roku, w którym współczynnik hydrotermiczny Sielianinowa wynosił 1,50. Natomiast najniższą wartość współczynnika hydrotermicznego odnotowano w sezonie wegetacyjnym 2015 roku - wynosiła ona 0,99 . W sezonie tym miesiąc sierpień charakteryzował się silną posuchą, a współczynnik hydrotermiczny wynosił 0,11 (tab. 1).

Tabela 1. Współczynniki hydrotermiczne Sielianinowa w czasie wegetacji ziemniaka (2015-2017)

Table 1. Selyaninov's hydrothermal coefficients during the potato vegetation (2015-2017)

\begin{tabular}{c|c|c|c|c|c|c|c|c}
\hline \multirow{2}{*}{$\begin{array}{c}\text { Lata } \\
\text { Years }\end{array}$} & \multicolumn{7}{c}{ Miesiące - Months } & \multicolumn{2}{c}{$\begin{array}{c}\text { Średnio } \\
\text { Mean } \\
\text { IV-IX }\end{array}$} \\
\cline { 2 - 9 } & IV & V & VI & VII & VIII & IX & 1,66 & 0,99 \\
\hline \multicolumn{7}{c}{ Współczynnik hydrotermiczny Sielianinowa* - Sielianinov's hydrothermic coefficient* } \\
\hline 2015 & 1,43 & 2,28 & 0,59 & 0,80 & 0,11 & 0,26 & 1,00 \\
\hline 2016 & 1,19 & 0,47 & 1,53 & 1,97 & 0,48 & $0,2,37$ & 1,50 \\
\hline
\end{tabular}

*wartość współczynnika - coefficient value (Bac i wsp. 1998)

do 0,50 - silna posucha - severe drought

$0,51-0,69$ - posucha - drought

$0,70-0,99$ - słaba posucha - weak drought

$\geq 1$ - brak posuchy - no drought 


\section{Wyniki i dyskusja / Results and discussion}

Powietrznie suchą masę chwastów zarówno na początku wegetacji ziemniaka (tab. 2), jak również przed zbiorem bulw (tab. 3) istotnie różnicowały właściwości odmianowe, sposoby pielęgnacji i warunki pogodowe panujące w latach badań (tab. 1). Dominującymi gatunkami chwastów były: Echinochloa crus-galli (L.) P. Beauv., Convolvulus arvensis L., Chenopodium album L., Galinsoga parviflora Cav., Viola arvensis Murr.

Zarówno przed zwarciem rzędów ziemniaka, jak również przed zbiorem bulw odnotowano istotnie większą powietrznie suchą masę chwastów w łanach odmiany Owacja, niż w łanach pozostałych odmian (średnio $28,5 \mathrm{~g} / \mathrm{m}^{2}$ przed zwarciem rzędów i 79,3 $\mathrm{g} / \mathrm{m}^{2}$ przed zbiorem bulw) (tab. 2, 3). Natomiast najmniejszą wartość omawianej cechy stwierdzono na obiektach, na których uprawiano odmianę Bellarosa (średnio 19,2 $\mathrm{g} / \mathrm{m}^{2}$ przed zwarciem rzędów i 49,7 $\mathrm{g} / \mathrm{m}^{2}$ przed zbiorem bulw) (tab. 2, 3). W prowadzonym eksperymencie odmiana Bellarosa była najbardziej konkurencyjna w stosunku do zachwaszczenia, jej części nadziemne były najwyższe, charakteryzowała się bogatym ulistnieniem, najsilniej zakrywała międzyrzędzia i nie pozwalała na rozwój chwastów. Wyniki te są zgodne z badaniami Sawickiej i wsp. (2011), którzy stwierdzili, że czynnikiem najsilniej modyfikującym masę chwastów były właściwości fizjologiczno-morfologiczne badanych odmian. Zdaniem autorów ocena konkurencyjności odmian ziemniaka wobec chwastów powinna być włączona jako jedno z kryteriów oceny ich wartości gospodarczej, tak jak w przypadku chorób i szkodników.

Odporność odmian ziemniaka na zachwaszczenie uwarunkowana jest $\mathrm{w}$ dużym stopniu, nie tylko ich właściwościami genetycznymi, ale również zawartością substancji organicznej w glebie, rodzajem i terminem wykonywania zabiegów agrotechnicznych, przebiegiem warunków pogodowych (Sawicka i wsp. 2006; Gugała i wsp. 2017) oraz zapasem diaspor $w$ glebie (Wojciechowski i Sowiński 2007).

$\mathrm{W}$ prowadzonym eksperymencie powietrznie sucha masa chwastów w obydwu terminach oznaczeń zależała istotnie od sposobów pielęgnacji łanu ziemniaka (tab. 2,3). Na obiektach, na których aplikowano biostymulator Asahi SL bądź GreenOK Universal - PRO (obiekt 2,3) powietrznie sucha masa chwastów była istotnie większa w porównaniu z obiektem kontrolnym, pielęgnowanym wyłącznie mechanicznie. Wynosiła ona odpowiednio przed zwarciem rzędów (średnio 38,1 i $37,9 \mathrm{~g} / \mathrm{m}^{2}$ ) (tab. 2) i przed zbiorem bulw (średnio 103,7 i 99,2 g/m²) (tab. 3). Wyniki te są zgodne z badaniami Sawickiej i wsp. (2011), którzy stwierdzili, że preparat Asahi SL przyczynił się do zwiększenia zachwaszczenia plantacji ziemniaka poprzez stymulację wzrostu dominujących gatunków chwastów. Najmniejszą średnią wartość powietrznie suchej masy chwastów zarówno przed zwarciem rzędów, jak i przed zbiorem bulw ziemniaka stwierdzono na obiekcie 4 i 5 , na których do wschodów roślin stosowano pielęgnację mechaniczną i tuż przed wschodami aplikowano herbicyd Avatar 293 ZC (obiekt 5), bądź też do

Tabela 2. Powietrznie sucha masa chwastów przed zwarciem rzędów ziemniaka $\left[\mathrm{g} / \mathrm{m}^{2}\right]$

Table 2. Air-dry matter of weeds before row closure of potatoes $\left[\mathrm{g} / \mathrm{m}^{2}\right]$

\begin{tabular}{|c|c|c|c|c|c|c|c|}
\hline \multirow{2}{*}{$\begin{array}{c}\text { Sposób pielęgnacji } \\
\text { Weed control } \\
\text { methods }\end{array}$} & \multicolumn{3}{|c|}{ Odmiana - Variety } & \multicolumn{3}{|c|}{ Lata - Years } & \multirow{2}{*}{$\begin{array}{c}\text { Średnio } \\
\text { Mean }\end{array}$} \\
\hline & Bellarosa & Owacja & Vineta & 2015 & 2016 & 2017 & \\
\hline $1 *$ & 24,1 & 41,1 & 32,8 & 22,3 & 31,5 & 44,2 & 32,6 \\
\hline 2 & 32,6 & 44,8 & 36,9 & 28,4 & 34,3 & 51,7 & 38,1 \\
\hline 3 & 30,6 & 45,4 & 37,7 & 27,8 & 33,9 & 52,0 & 37,9 \\
\hline 4 & 4,8 & 6,1 & 5,4 & 4,0 & 5,6 & 6,7 & 5,4 \\
\hline 5 & 4,2 & 5,1 & 4,9 & 3,8 & 4,9 & 5,5 & 4,7 \\
\hline $\begin{array}{l}\text { Średnio } \\
\text { Mean }\end{array}$ & 19,2 & 28,5 & 23,5 & 17,2 & 22,0 & 32,0 & 23,7 \\
\hline \multicolumn{7}{|c|}{ NIR $(0,05)-\operatorname{LSD}(0.05)$} & \\
\hline \multicolumn{7}{|c|}{ Lata - Years } & 2,770 \\
\hline \multicolumn{7}{|c|}{ Odmiana - Variety } & 2,770 \\
\hline \multicolumn{7}{|c|}{ Sposób pielęgnacji - Weed control methods } & 2,166 \\
\hline \multicolumn{7}{|c|}{ Lata $\times$ odmiana - Years $\times$ cultivar } & r.n. \\
\hline \multicolumn{7}{|c|}{ Lata $\times$ sposób pielęgnacji - Years $\times$ weed control method } & 3,752 \\
\hline \multicolumn{7}{|c|}{ Odmiana $\times$ sposób pielęgnacji - Variety $\times$ weed control method } & r.n. \\
\hline
\end{tabular}

r.n. - różnica nieistotna - not significant difference

*jak w metodyce badań - as in the research methodology:

1 - obiekt kontrolny (bez biostymulatorów i herbicydu) - control (without biostimulators and herbicide)

2 - GreenOK Universal - PRO $0,10 \mathrm{dm}^{3} / \mathrm{ha}+0,15 \mathrm{dm}^{3} / \mathrm{ha}+0,15 \mathrm{dm}^{3} / \mathrm{ha}$

3 - Asahi SL $0,50 \mathrm{dm}^{3} / \mathrm{ha}+0,50 \mathrm{dm}^{3} / \mathrm{ha}+0,50 \mathrm{dm}^{3} / \mathrm{ha}$

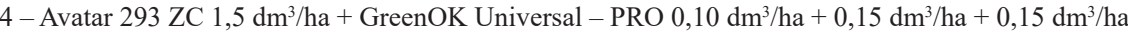

5 - Avatar $293 \mathrm{ZC} 1,5 \mathrm{dm}^{3} / \mathrm{ha}$ 
Tabela 3. Powietrznie sucha masa chwastów przed zbiorem bulw ziemniaka $\left[\mathrm{g} / \mathrm{m}^{2}\right]$

Table 3. Air-dry matter of weeds before harvest of potato tubers $\left[\mathrm{g} / \mathrm{m}^{2}\right]$

\begin{tabular}{|c|c|c|c|c|c|c|c|}
\hline \multirow{2}{*}{$\begin{array}{c}\text { Sposoby } \\
\text { pielęgnacji } \\
\text { Weed control } \\
\text { methods }\end{array}$} & \multicolumn{3}{|c|}{ Odmiana - Variety } & \multicolumn{3}{|c|}{ Lata - Years } & \multirow{2}{*}{$\begin{array}{c}\text { Średnio } \\
\text { Mean }\end{array}$} \\
\hline & Bellarosa & Owacja & Vineta & 2015 & 2016 & 2017 & \\
\hline $1 *$ & 68,0 & 117,1 & 95,6 & 67,3 & 89,8 & 123,6 & 93,5 \\
\hline 2 & 79,5 & 128,1 & 103,6 & 76,1 & 100,4 & 134,7 & 103,7 \\
\hline 3 & 77,6 & 120,9 & 99,3 & 72,8 & 95,0 & 130,1 & 99,2 \\
\hline 4 & 12,3 & 16,5 & 14,7 & 12,2 & 14,5 & 16,7 & 14,4 \\
\hline 5 & 11,2 & 13,9 & 13,2 & 10,5 & 12,8 & 9,0 & 11,7 \\
\hline $\begin{array}{c}\text { Średnio } \\
\text { Mean }\end{array}$ & 49,7 & 79,3 & 65,2 & 47,7 & 62,5 & 82,8 & 64,5 \\
\hline \multicolumn{8}{|c|}{$\operatorname{NIR}(0,05)-\operatorname{LSD}(0.05)$} \\
\hline \multicolumn{7}{|c|}{ Lata - Years } & 2,766 \\
\hline \multicolumn{7}{|c|}{ Odmiana - Variety } & 2,766 \\
\hline \multicolumn{7}{|c|}{ Sposób pielęgnacji - Weed control method } & 3,524 \\
\hline \multicolumn{7}{|c|}{ Lata $\times$ odmiana - Years $\times$ cultivar } & r.n. \\
\hline \multicolumn{7}{|c|}{ Lata $\times$ sposób pielęgnacji - Years $\times$ weed control method } & 6,104 \\
\hline \multicolumn{7}{|c|}{ Odmiana $\times$ sposób pielęgnacji - Variety $\times$ weed control method } & 5,213 \\
\hline
\end{tabular}

r.n. - różnica nieistotna - not significant difference

*jak w metodyce badań - as in the research methodology:

1 - obiekt kontrolny (bez biostymulatorów i herbicydu) - control (without biostimulators and herbicide)

2 - GreenOK Universal - PRO $0,10 \mathrm{dm}^{3} / \mathrm{ha}+0,15 \mathrm{dm}^{3} / \mathrm{ha}+0,15 \mathrm{dm}^{3} / \mathrm{hal}$

3 - Asahi SL $0,50 \mathrm{dm}^{3} / \mathrm{ha}+0,50 \mathrm{dm}^{3} / \mathrm{ha}+0,50 \mathrm{dm}^{3} / \mathrm{ha}$

4 - Avatar $293 \mathrm{ZC} 1,5 \mathrm{dm}^{3} / \mathrm{ha}+$ GreenOK Universal - PRO 0,10 $\mathrm{dm}^{3} / \mathrm{ha}+0,15 \mathrm{dm}^{3} / \mathrm{ha}+0,15 \mathrm{dm}^{3} / \mathrm{ha}$

5 - Avatar $293 \mathrm{ZC} 1,5 \mathrm{dm}^{3} / \mathrm{ha}$

wschodów poletka pielęgnowano mechanicznie, a tuż przed wschodami roślin ziemniaka aplikowano herbicyd Avatar 293 ZC i następnie po wschodach trzykrotnie biostymulator GreenOK Universal - PRO (obiekt 4) (tab. 2, 3).

Istotne różnice $\mathrm{w}$ powietrznie suchej masie chwastów zanotowano także w poszczególnych latach uprawy. Największą wartość omawianej cechy odnotowano w sezonie wegetacyjnym 2017 roku, który był najbardziej wilgotny w odniesieniu do pozostałych lat badań. Stwierdzono również istotną interakcję sposobów pielęgnacji z latami i sposobów pielęgnacji z odmianami, która potwierdza, że działanie zastosowanych agrochemikaliów było zależne od warunków wilgotnościowo-termicznych panujących podczas wegetacji oraz odmienna była reakcja odmian na stosowane preparaty.

Z przeprowadzonych badań wynika, że zniszczenie chwastów było większe pod koniec wegetacji, niż przed zwarciem rzędów ziemniaka. Wynosiło ono średnio 84,0\% przed zwarciem rzędów i $85,4 \%$ przed zbiorem bulw (tab. 4, 5).

W ograniczaniu zachwaszczenia $\mathrm{w}$ obydwu terminach oznaczeń bardziej skuteczna okazała się pielęgnacja mechaniczna do wschodów i tuż przed wschodami aplikacja herbicydu Avatar $293 \mathrm{ZC}$ w dawce $1,5 \mathrm{dm}^{3} / \mathrm{ha}$

Tabela 4. Skuteczność regulacji zachwaszczenia przed zwarciem rzędów ziemniaka

Table 4. Efficacy of weed control before row closure of the potatoes

\begin{tabular}{|c|c|c|c|c|c|c|c|}
\hline \multirow{3}{*}{$\begin{array}{c}\text { Sposoby } \\
\text { pielęgnacji } \\
\text { Weed control } \\
\text { methods }\end{array}$} & \multirow{2}{*}{\multicolumn{3}{|c|}{$\begin{array}{c}\begin{array}{c}\text { Zniszczenie chwastów } \\
\text { Weed control } \\
{[\%]}\end{array} \\
\text { odmiana - variety }\end{array}$}} & \multirow{2}{*}{\multicolumn{3}{|c|}{ Lata - Years }} & \multirow{3}{*}{$\begin{array}{c}\text { Średnio } \\
\text { Mean }\end{array}$} \\
\hline & & & & & & & \\
\hline & Bellarosa & Owacja & Vineta & 2015 & 2016 & 2017 & \\
\hline $1 *$ & 24,1 & 41,1 & 32,8 & 22,3 & 31,5 & 44,2 & - \\
\hline 4 & 80,1 & 85,2 & 83,6 & 82,1 & 82,3 & 84,9 & 83,0 \\
\hline 5 & 82,6 & 87,6 & 85,1 & 83,0 & 84,5 & 87,6 & 85,0 \\
\hline $\begin{array}{c}\text { Średnio } \\
\text { Mean }\end{array}$ & 81,3 & 86,4 & 84,3 & 82,5 & 83,4 & 86,2 & 84,0 \\
\hline
\end{tabular}

*jak w metodyce badań - as in the research methodology:

1 - obiekt kontrolny (bez biostymulatorów i herbicydu) - standard object (without biostimulators and herbicide)

4 - Avatar $293 \mathrm{ZC} 1,5 \mathrm{dm}^{3} / \mathrm{ha}+$ GreenOK Universal - PRO $0,10 \mathrm{dm}^{3} / \mathrm{ha}+0,15 \mathrm{dm}^{3} / \mathrm{ha}+0,15 \mathrm{dm}^{3} / \mathrm{ha}$

5 - Avatar $293 \mathrm{ZC} 1,5 \mathrm{dm}^{3} / \mathrm{ha}$ 
Tabela 5. Skuteczność regulacji zachwaszczenia przed zbiorem bulw ziemniaka Table 5. Efficacy of weed control before harvest of the potato

\begin{tabular}{|c|c|c|c|c|c|c|c|}
\hline \multirow{3}{*}{$\begin{array}{c}\text { Sposoby } \\
\text { pielęgnacji } \\
\text { Weed control } \\
\text { methods }\end{array}$} & \multirow{2}{*}{\multicolumn{3}{|c|}{$\begin{array}{c}\text { Zniszczenie chwastów } \\
\text { Weed control } \\
{[\%]} \\
\text { odmiana - variety }\end{array}$}} & \multirow{2}{*}{\multicolumn{3}{|c|}{ Lata - Years }} & \multirow{3}{*}{$\begin{array}{c}\text { Średnio } \\
\text { Mean }\end{array}$} \\
\hline & & & & & & & \\
\hline & Bellarosa & Owacja & Vineta & 2015 & 2016 & 2017 & \\
\hline $1^{*}$ & 68,0 & 117,1 & 95,6 & 67,3 & 89,8 & 123,6 & - \\
\hline 4 & 82,0 & 86,0 & 84,7 & 81,9 & 83,9 & 86,5 & 84,1 \\
\hline 5 & 83,6 & 88,2 & 86,2 & 84,4 & 85,8 & 92,8 & 86,8 \\
\hline $\begin{array}{l}\text { Średnio } \\
\text { Mean }\end{array}$ & 82,8 & 87,1 & 85,4 & 83,1 & 84,9 & 89,6 & 85,4 \\
\hline
\end{tabular}

*jak w metodyce badań - as in the research methodology:

1 - obiekt kontrolny (bez biostymulatorów i herbicydu) - control (without biostimulators and herbicide)

4 - Avatar $293 \mathrm{ZC} 1,5 \mathrm{dm}^{3} / \mathrm{ha}+$ GreenOK Universal - PRO 0,10 $\mathrm{dm}^{3} / \mathrm{ha}+0,15 \mathrm{dm}^{3} / \mathrm{ha}+0,15 \mathrm{dm}^{3} / \mathrm{ha}$

5 - Avatar $293 \mathrm{ZC} 1,5 \mathrm{dm}^{3} / \mathrm{ha}$

(obiekt 5), niż do wschodów pielęgnacja mechaniczna i tuż przed wschodami aplikacja herbicydu Avatar 293 ZC w dawce $1,5 \mathrm{dm}^{3} /$ ha i następnie po wschodach trzykrotne opryskiwanie bioaktywatorem GreenOK Universal - PRO w dawce $0,10 \mathrm{dm}^{3} /$ ha (pełnia-koniec wschodów) $+0,15 \mathrm{dm}^{3} /$ ha (zakrywanie międzyrzędzi) $+0,15 \mathrm{dm}^{3} /$ ha (zawiązywanie pąków kwiatowych) (obiekt4) (tab. 5, 6). Procent zniszczenia chwastów na tych obiektach w obydwu terminach oznaczeń wynosił odpowiednio: 85,0 i 86,8\% (obiekt 5) oraz 83,0 i $84,1 \%$ (obiekt 4) (tab. 4, 5). Natomiast Domaradzki i wsp. (2015) w prowadzonym eksperymencie nie stwierdzili wpływu sposobu aplikacji herbicydów (z biostymulatorem lub bez) na końcową skuteczność niszczenia chwastów. Gugała i wsp. (2017), najmniejsze zachwaszczenie plantacji ziemniaka uzyskali stosując herbicydy i biostymulatory wzrostu.

\section{Wnioski / Conclusions}

1. Najmniejsze zachwaszczenie plantacji ziemniaka uzyskano po zastosowaniu herbicydu (obiekt 5) oraz herbicydu i biostymulatora (obiekt 4). Bioregulatory wzrostu GreenOK Universal - PRO i Asahi SL przyczyniły się do wzrostu zachwaszczenia w porównaniu z obiektem kontrolnym, pielęgnowanym wyłącznie mechanicznie.

2. Zachwaszczenie plantacji ziemniaka istotnie modyfikowały właściwości genetyczne odmian. Najmniej zachwaszczona była odmiana Bellarosa, której części nadziemne najsilniej zakrywały międzyrzędzia i nie pozwalały na rozwój chwastów.

3. Wykazano interakcję lat z czynnikami doświadczenia, która potwierdza, że zachwaszczenie plantacji, jak również efekty odchwaszczania różnicowały warunki pogodowe w latach badań.

\section{Literatura / References}

Babuška P. 2004. Asahi kompendium wiedzy. ASAHI Chemical, Japonia: 1-30.

Badowski M., Domaradzki K., Filipiak K., Franek M., Gołębiowska H., Kieloch R., Kucharski M., Rola H., Rola J., Sadowski J., Sekutowski T., Zawerbny T. 2001. Metodyka doświadczeń biologicznej oceny herbicydów, bioleguratorów i adiuwantów. Cz. I. Doświadczenia polowe. Instytut Uprawy Nawożenia i Gleboznawstwa, Wrocław, 167 ss.

Bac S., Koźmiński Cz., Rojek M. 1998. Agrometerologia. Państwowe Wydawnictwo Naukowe, Warszawa, 274 ss.

Barabaś P. 2015. Ochrona plantacji ziemniaka przed zachwaszczeniem. Ziemniak Polski 1: 11-17.

Czeczko R., Mikos-Bielak M. 1997. Effect of applying the Atonik-Japanese growth stimulator in vegetables cultivation. In: Cost 915-Copernicus CIPA-CT 940120, Workshop on Food Quality Modelling (J. De Baerdemaeker, ed.). Katholieke Universiteit Leuven, Leuven, 04-06.07.1997: 39 .

Domaradzki K., Marczewska-Kolasa K., Bortniak M. 2015. Ocena skuteczności mieszaniny herbicydów i biostymulatorów w uprawie buraka cukrowego. [Evaluation of the effectiveness of a mixture of herbicides and biostimulators in the cultivation of sugar beet]. Przemysł Chemiczny 5 (94): 787-792. DOI: 10.15199/62.2015.5.28.

Gajewski P., Kaczmarek Z., Owczarzak W., Jakubas M., Mocek A. 2013. Wpływ dodatków organicznych oraz preparatu EM-A na właściwości fizyczne, chemiczne oraz na stan struktury poziomu orno-próchnicznego gleby uprawnej. Część III. Stan struktury. [Impact of addition of organic additives and EM-A preparation on physical, chemical and structural state of the arable-humus soil horizon. Part III. Structure state]. Journal of Research and Applications in Agricultural Engineering 58 (3): 119-123.

Gruczek T. 2004. Chemiczne i mechaniczne zwalczanie chwastów w ziemniakach oraz wpływ na jakość plonu. [Weed control in potato crop under increased occurrence of cockspur panicum Echinochloa crus-galli (L.) and the influence on potato tuber quality]. Progress in Plant Protection/Postępy w Ochronie Roślin 44 (2): 715-717. 
Gugała M., Zarzecka K., Sikorska A., Mystkowska I., Dołęga H. 2017. Wpływ herbicydów i biostymulatorów wzrostu na ograniczenie zachwaszczenia i plonowanie ziemniaka jadalnego. [Effect of herbicides and growth biostimulants on weed reduction and yield of edible potato]. Fragmenta Agronomica 34 (4): 59-66.

Jovović Z., Latinović N., Velimirović A., Popović T., Stešević D., Poštić D. 2012. Effect of chemical weed treatment on weediness and of potato yield. Herbologia 13 (2): 51-59.

Kołodziejczyk M. 2016. Effect of nitrogen fertilisation and microbial preparations on quality and storage losses in edible potato. [Wpływ nawożenia azotem i preparatów mikrobiologicznych na kształtowanie się jakości oraz strat przechowalniczych ziemniaka jadalnego]. Acta Agrophysica 23 (1): 67-78.

Kowalska J. 2016. Effect of fertilization and microbiological bio-stimulators on healthiness and yield of organic potato. [Wpływ nawożenia oraz biostymulatorów mikrobiologicznych na zdrowotność i plonowanie ziemniaka w systemie ekologicznym]. Progress in Plant Protection 56 (2): 230-235. DOI: 10.14199/ppp-2016-039.

Nowacki W., Podolska G. 2005. Intensywność technologii a jakość ziemiopłodów. Materiały IX Konferencji Naukowej „Efektywne i bezpieczne technologie produkcji roślinnej”. Puławy, 1-2.06.2005: 135-140.

Paradiković N., Vinković T., Vinković Vrček I., Žuntar I., Bojić M., Medić-Šarić M. 2011. Effect of natural biostimulants on yield and nutritional quality: an example of sweet yellow pepper (Capsicum annuum L.) plants. Journal of the Science of Food and Agriculture 91 (12): 2146-2152. DOI: $10.1002 /$ jsfa.4431.

Pytlarz-Kozicka M. 2002. Wpływ sposobów pielęgnowania na wysokość i jakość plonów ziemniaka. [The effect of treatment methods on the quantity and quality of potato yield]. Zeszyty Problemowe Postępów Nauk Rolniczych 489: 147-155.

Roztropowicz S. 1999. Metodyka obserwacji, pomiarów i pobierania prób w agrotechnicznych doświadczeniach z ziemniakiem. Wydawnictwo Instytutu Hodowli i Aklimatyzacji Roślin, Oddział w Jadwisinie: 1-50.

Sawicka B., Barbaś P., Dąbek-Gad M. 2011. Problem zachwaszczenia w warunkach stosowania bioregulatorów wzrostu i nawożenia dolistnego w uprawie ziemniaka. [The problem of weed infestation in conditions of applying the growth bioregulators and foliar fertilization in potato cultivation]. Nauka Przyroda Technologie 5 (2): \#9.

Sawicka B., Barbaś P., Kuś J. 2006. Wpływ zachwaszczenia łanu na plon ogólny i handlowy bulw ziemniaka w warunkach ekologicznego $\mathrm{i}$ integrowanego systemu produkcji. [The influence of weed infestation of potato canopy on the total and trade yield under organic and integrated crop production systems]. Pamiętnik Puławski 142: 429-443.

Sawicka B., Pszczółkowski P. 2003. Próby ograniczenia zachwaszczenia łanu ziemniaka w uprawie pod osłonami. Część III. Wpływ zachwaszczenia łanu na plon ogólny i handlowy bulw. [Attempts to control infestation of potato canopy cultivated under shields. Part III. The effect of weed overgrowth in the stand upon the total and market yield of tubers]. Biuletyn Instytutu Hodowli i Aklimatyzacji Roślin 228: 233-247.

Urbanowicz J. 2012. Występowanie chwastów w ziemniaku oraz metody ich zwalczania na terenie Polski w latach 2000-2011. [The occurrence of weeds and methods of their control in potatoes in Poland in the years 2000-2011]. Biuletyn Instytutu Hodowli i Aklimatyzacji Roślin 265: 129-135.

Urbanowicz J. 2015. Herbicydy zalecane do ochrony ziemniaka. Ziemniak Polski 2: 25-29.

Wojciechowski W., Sowiński J. 2007. Wpływ sposobu zagospodarowania pól na zapas diaspor chwastów w glebie. [The effect of field management on weed seed bank in the soil]. Annales Universitatis Mariae Curie-Skłodowska, Sectio E, Agricultura 62 (2): 33-39.

Zarzecka K. 2000. Zależność plonowania ziemniaka od zachwaszczenia. Fragmenta Agronomica 17 (2): 120-134.

Zarzecka K., Gugała M. 2004. Kształtowanie się zachwaszczenia odmian ziemniaka w zależności od sposobu pielęgnacji. [Weed infestation of potato crops depending on weed control methods]. Biuletyn Instytutu Hodowli i Aklimatyzacji Roślin 232: 177-184. 